\title{
The formation of formates: a review of metal formates on heritage objects
}

\author{
Gerhard Eggert ${ }^{*}$ (iD and Andrea Fischer
}

\begin{abstract}
Metal formates sometimes occur as degradation products on heritage objects due to the use of wood products or other sources of formic acid and formaldehyde. They are often related to alkaline surfaces which transform formaldehyde directly into formate. The dominant role of formate on alkaline surfaces, for example in glass-induced metal corrosion (GIM) or calcium carbonate degradation, was explored in the Stuttgart research on rare heritage corrosion products. This review discusses these findings together with those from the literature: ocurrences of sodium and potassium formate on glass, calcium formate and calcium acetate-formate phases on calcareous materials, magnesium formate on Sorel cement and dolomitic sandstone, lead formate on metal and pigments, cadmium formate on coated objects, as well as various copper and zinc formates on copper alloys. In the latter cases, formates dominate as glass-induced metal corrosion products. The formation of formates constitutes irreversible damage, degrading the material of heritage objects. Therefore, preventive conservation needs to remove all sources of carbonyl pollutants in order to avoid such corrosion.
\end{abstract}

Keywords: Calcium, Copper, Formaldehyde, Formate, Formic acid, Glass-induced metal corrosion, Lead, Magnesium, Sodium, Zinc

\section{Introduction}

Reports on the occurrence of metal formates on heritage objects have increased considerably in recent decades. While there are only six entries for 'formate' in the conservation database AATA [1] before 1980, eleven for the $80 \mathrm{~s}$ and nine for the $90 \mathrm{~s}$, this doubled to 19 in the 2000s (and there have been another 19 up until the last update for 2018). This is mainly due to the greater awareness of the detrimental effects of pollutants on heritage objects and the better availability of instrumental analysis in conservation. X-ray powder diffraction (XRPD), recorded with Debye-Scherrer cameras, has been in use for a long time in conservation science for the identification of known crystalline compounds. Modern high precision measurements now even allow the quantifying of mixtures and the derivation of crystal structures. $\mu$-Raman Spectroscopy has become widely used and allows the analysis of individual

*Correspondence: gerhard.eggert@abk-stuttgart.de State Academy of Art and Design, Am Weißenhof 1, 70191 Stuttgart, Germany particles for the presence of formate as does $\mu$-FTIR. In the Stuttgart RaCoPHINO (= Rare Corrosion Phenomena of Inorganic Objects) research, the dominant role of formate on alkaline surfaces, e.g., in glass-induced metal corrosion (GIM) or calcium carbonate degradation, was explored. These new findings are reviewed here, together with those from the literature [2] to give an overview of the state of knowledge about the occurrence of formates on heritage objects. All occurring compounds of known formula are listed in Table 1 as an overview.

Table 1 List of metal formates with known formula detected on heritage objects

\begin{tabular}{|c|c|c|}
\hline Chemical name & Formula & Other names \\
\hline Sodium formate & $\mathrm{NaHCOO}$ & \\
\hline Potassium formate & KHCOO & \\
\hline $\begin{array}{l}\text { Magnesium formate } \\
\text { dihydrate }\end{array}$ & $\mathrm{Mg}(\mathrm{HCOO})_{2} \cdot 2 \mathrm{H}_{2} \mathrm{O}$ & Dashkovaite \\
\hline a-Calcium formate & $\mathrm{Ca}(\mathrm{HCOO})_{2}$ & \\
\hline
\end{tabular}

\section{Springer Open}

(c) The Author(s) 2021, corrected publication 2021. This article is licensed under a Creative Commons Attribution 4.0 International License, which permits use, sharing, adaptation, distribution and reproduction in any medium or format, as long as you give appropriate credit to the original author(s) and the source, provide a link to the Creative Commons licence, and indicate if changes were made. The images or other third party material in this article are included in the article's Creative Commons licence, unless indicated otherwise in a credit line to the material. If material is not included in the article's Creative Commons licence and your intended use is not permitted by statutory regulation or exceeds the permitted use, you will need to obtain permission directly from the copyright holder. To view a copy of this licence, visit http://creativecommons.org/licenses/by/4.0/. The Creative Commons Public Domain Dedication waiver (http://creativeco mmons.org/publicdomain/zero/1.0/) applies to the data made available in this article, unless otherwise stated in a credit line to the data. 


\begin{tabular}{|c|c|c|}
\hline Chemical name & Formula & Other names \\
\hline $\begin{array}{l}\text { Calcium acetate formate } \\
\text { monohydrate }\end{array}$ & $\begin{array}{l}\mathrm{Ca}\left(\mathrm{CH}_{3} \mathrm{COO}\right) \\
(\mathrm{HCOO}) \cdot \mathrm{H}_{2} \mathrm{O}\end{array}$ & Tennent's salt \\
\hline $\begin{array}{l}\text { Calcium acetate formate } \\
\text { dinitrate tetrahydrate }\end{array}$ & $\begin{array}{l}\mathrm{Ca}_{2}\left(\mathrm{CH}_{3} \mathrm{COO}\right)(\mathrm{HCOO}) \\
\left(\mathrm{NO}_{3}\right)_{2} \cdot 4 \mathrm{H}_{2} \mathrm{O}\end{array}$ & \\
\hline Lead formate & $\mathrm{Pb}(\mathrm{HCOO})_{2}$ & \\
\hline $\begin{array}{l}\text { Copper sodium formate } \\
\text { hydroxide oxide hydrate }\end{array}$ & $\begin{array}{c}\mathrm{Cu}_{4} \mathrm{Na}_{4} \mathrm{O}(\mathrm{HCOO})_{8} \\
(\mathrm{OH})_{2} \cdot 4 \mathrm{H}_{2} \mathrm{O}\end{array}$ & $\begin{array}{l}\text { Basic sodium } \\
\text { copper formate, } \\
\text { formerly: socofor- } \\
\text { macite }\end{array}$ \\
\hline $\begin{array}{l}\text { Copper formate trihy- } \\
\text { droxide }\end{array}$ & $\left.\mathrm{Cu}_{2} \mathrm{HCOO}\right)(\mathrm{OH})_{3}$ & $\begin{array}{l}\text { Dicopper trihydroxy } \\
\text { formate }\end{array}$ \\
\hline Zinc formate dihydrate & $\mathrm{Zn}(\mathrm{HCOO})_{2} \cdot 2 \mathrm{H}_{2} \mathrm{O}$ & \\
\hline $\begin{array}{l}\text { Zinc copper formate } \\
\text { hydroxide hydrate }\end{array}$ & $\begin{array}{c}\mathrm{Zn}_{4} \mathrm{Cu}_{3}\left(\mathrm{Zn}_{1-\mathrm{x}} \mathrm{Cu}_{\mathrm{x}}\right)_{6} \\
(\mathrm{HCOO})_{8} \\
(\mathrm{OH})_{18} \cdot 6\left(\mathrm{H}_{2} \mathrm{O}\right)\end{array}$ & Zinc C \\
\hline $\begin{array}{l}\text { Cadmium formate dihy- } \\
\text { drate }\end{array}$ & $\mathrm{Cd}(\mathrm{HCOO})_{2} \cdot 2 \mathrm{H}_{2} \mathrm{O}$ & \\
\hline
\end{tabular}

The occurrence of formates on heritage objects indicates that an irreversible degradation of original material has occurred. Their detection forms the base for informed interventive and preventive conservation.

\section{Sources of formate \\ Formic acid}

Exposure to formic (=methanoic) acid, $\mathrm{HCOOH}$, causes the formation of its salts, the formates (=methanoates), $\mathrm{HCOO}^{-}$, on susceptible materials. Wood emits considerable amounts of formic acid [3]. Its use with heritage objects or as material for their storage, especially in enclosed spaces (boxes, cupboards, display cases), is the main reason for formate formation. Rivers and Umney [4] mention that the use of formic acid for tanning of some leathers, in the coagulation of rubber latex, and as a catalyst for certain adhesives also causes damage.

Formic acid also occurs as a by-product of the oxidation of unsaturated aldehydes: These are formed by the decomposition of primary unsaturated ester hydroperoxides from the autoxidation of oils [5] used as binding media. The acid can then react with pigments in paint layers [6].

There is, however, another source which should be kept in mind: As documented in older conservation textbooks, formic acid itself has been, in the past, used intentionally in the treatment of objects. Examples are the removal of calcareous concretions on geological specimens (e.g., fluorapatite [7]), on ceramics $[8,9]$ and bone [9] or the cleaning of weathered outdoor stones [10]. Plenderleith [11] reduced horn silver $(\mathrm{AgCl})$ in formic acid with aluminium or zinc or electrical current. Formic acid allows the dissolving of copper compounds from silver finds [12] 'without affecting silver or silver chloride' [11]. Thickett and Enderley [13] found it less aggressive for the removal of cuprite from silver coins than sulfuric acid/sodium carbonate treatments, formic acid is still in use today [14]. To remove silver tarnish and avoid mineral acids, as contained in commercial silver dips, the conservation literature even lists recipes, replacing them by formic acid alone [9] or in formulations with thiourea [15-17]. Copper alloys including gilded ones can be stripped with formic acid from corrosion products [4, 18]. Intensive washing is recommended in these recipes and formic acid itself is volatile. However, ionic metal formates as reaction products might be left behind as residues in pores and cracks.

\section{Formaldehyde}

Since the seminal publication of 1987 [19], conservators are well aware of the danger of formaldehyde to museum collections. Formaldehyde is an ubiquitous air pollutant emitted from a great number of indoor sources including wood products, textiles, paints, etc.; the average concentration in European households is around 20-30 $\mu \mathrm{g} /$ $\mathrm{m}^{3}$ [20]. Formaldehyde $\left(\mathrm{H}_{2} \mathrm{CO}\right)$ can be oxidised to formic acid $(\mathrm{HCOOH})$, can therefore be seen as its precursor. But in model experiments, exposed lead coupons showed only slight tarnish, even at high humidity in the dark [21]. In the presence of light, photooxidation can produce traces of oxidising agents. Hydrogen peroxide in the atmosphere induces heavy lead corrosion in combination with formaldehyde [21]. Slow or hindered oxidation explains the relative rareness of metal formates, despite the availability of formaldehyde.

Under alkaline conditions, formaldehyde can be oxidised by itself (Cannizzaro disproportionation reaction) according to [22]:

$$
\mathrm{Na}^{+} \mathrm{OH}^{-}+2 \mathrm{H}_{2} \mathrm{CO} \rightarrow \mathrm{Na}^{+} \mathrm{HCOO}^{-}+\mathrm{CH}_{3} \mathrm{OH}
$$

Sodium hydroxide $(\mathrm{NaOH})$ occurs in the hydrolysis (ion exchange) of soda glass by aerial humidity; therefore, sodium formate, $\mathrm{NaHCOO}$, and not carbonate dominates on its surface. As electrolytes, the alkaline degradation films on glass are able to induce corrosion in neighbouring metals. Consequently, mainly formates were found as metal corrosion products in contact with glass in the Stuttgart research on glass-induced metal corrosion [23].

\section{Carbon monoxide}

Formerly, carbon monoxide (CO) from incomplete combustion of organic materials might have also played a role as airborne formic acid precursor on alkaline surfaces [24]. Today, sodium or potassium formate are synthesised from alkali hydroxide and carbon monoxide using heat and pressure, e.g. [24]: 


$$
\mathrm{NaOH}+\mathrm{CO} \rightarrow \mathrm{NaHCOO}
$$

As equilibrium reaction this can also happen to some degree in ambient conditions. Carbon monoxide concentrations in rooms where organic material is burnt (fireplaces, stoves, tobacco smoking, etc.) are in the order of some $10 \mathrm{ppm}$. Historically, this might even be more relevant for formate formation than trace gases like formic acid or formaldehyde in the parts per billion range. Experimental studies of this hypothesis seem worthwhile.

\section{Analytical determination}

Formates are normally present as efflorescence or corrosion products on objects, sampling is then no problem. With the possible exception of the mineraalgroen pigment samples in the Hafkenscheid collection [25], it does not occur as original material of objects.

Formate $\left(\mathrm{HCOO}^{-}\right)$is a four-atom anion with three chemical bonds of two different types $(\mathrm{C}-\mathrm{H}$ and $\mathrm{C}-\mathrm{O})$ which allows easy determination by vibrational spectroscopy. With only one carbon atom in the ion, it does not have a $\mathrm{C}-\mathrm{C}$ bond, so the absence of the Raman active symmetric stretch vibration in spectra $\left(\approx 940 \mathrm{~cm}^{-1}\right.$ in acetate) allows the distinction from higher carboxylates. As complementary method, energy dispersive X-ray analysis in the scanning electron microscope (EDX-SEM) is able to detect the metal cations and to visualise the particles.

Known crystalline phases (including their water of hydration) can be identified by X-ray powder diffraction (XRPD) and search in the large ICDD database with now more than 1,000,000 data sets in its powder diffraction files. Modern high precision measurements even allow the quantification of mixtures including the amount of amorphous material present. Some progress in research is due to the modern software based evaluation of powder diffraction data which allows the derivation of crystal structures and formulas for unknown crystalline compounds [26].

Access to sophisticated analytical instrumentation and trained staff is often limited in conservation departments. Therefore, simple microchemical tests are still widely used in conservation labs, but the standard textbook omits formate [27]. The chemical literature lists a number of reactions for the qualitative detection of formate [28]. The precipitation with cerium(III) nitrate (1\%) solution [29] as unambiguous reaction seems best suited for the distinction from other carboxylates under the microscope.

\section{Alkali metal formates}

Sodium and potassium formates have been detected on the surface of historic glass. These ions are introduced as flux during glass production. They can be leached out by atmospheric humidity and react further with pollutants on the surface.

In 1960, sodium formate was discovered for the first time on heritage objects by XRPD; Elisabeth West FitzHugh found it 'on many areas of an early sixteenth century Limoges enamel triptych in the Walters Art Gallery' [30, 31]. In 1978, it was detected on glass lids of modern boxes used to store archaeological textile fragments for some 40 years. Formaldehyde was given off by cardboard in the boxes [32]. In the 1980s, sodium formate crystals were found on the inner side of cover glasses of daguerreotype [33, 34]. Glass beads from the Museum of Ethnology in Berlin, stored in chipboard cupboards, were also affected by the same phenomenon [35]. White deposits of sodium formate formed within a few months. Model experiments showed that formaldehyde can produce such deposits on glass via the Cannizzaro reaction [35]. Sodium formate was also found on glass beads of a skirt of the 1920s [36] and a weeping Egyptian glass scarab [37]. Vessel glasses from the Swiss National Museum stored on chipboard shelves were also affected as was discovered by Schwarz in a diploma thesis at the Stuttgart State Academy of Art and Design [38].

In the National Museums of Scotland, white crystalline deposits were observed on a large number of 19th and 20th century British glass artefacts [39]. In display cases, major levels of acetic acid, and high levels of formic acid and formaldehyde, which exceed those in the gallery, were measured using passive air samplers. Ion chromatography (IC) showed that sodium and formate were the dominant ions in these deposits. Raman spectroscopy identified modifications of anhydrous sodium formate as the main phases and possibly some potassium formate in liquid droplets. Verhaar et al. [40] developed a protocol for sampling the surface of historic glass and quantitative analysis by ion-exchange chromatography. They studied eleven glass objects from various backgrounds and confirmed that formate dominates over carbonate [41], which is the only anion being formed in unpolluted air (from carbon dioxide).

Surprisingly, the whitening occurring on a painting on a newspaper also contained some sodium formate identified by XRPD. The sodium might originate from sodium carboxymethyl cellulose in the wallpaper paste used for glueing, the formate from the paper made from wood [42].

Sodium formate has a deliquescence relative humidity (DRH) of ca. $51 \%$ and, therefore, can be found as a solid deposit on glass surfaces when stored below that 
RH. Potassium formate (DRH $=19 \%$ [43]) is only present on glass surfaces in liquid droplets in a museum climate; Robinet et al. [39] reported evidence for their presence.

Other alkali metal formates containing copper ions are discussed below.

\section{Alkaline earth formates}

Strontium and barium e.g., in pigments and glass, are rare as components of heritage objects and no formates have been detected, as opposed to the more frequent magnesium and calcium. Both calcium formate and magnesium formate dihydrate have a DRH $>95 \%$ [44]; therefore, they are not hygroscopic.

\section{Calcium formates}

Calcareous exhibits are known to be attacked by organic acids emitted from display cases, a phenomenon named Byne's disease after its discoverer [45]. Various calcium acetate compounds, some containing also chloride, nitrate, and/or formate as anions are formed as efflorescence [46]. Although pure calcium formate is still named as a phase occurring in Byne's disease [47], no positive identification could be found in the literature [48]. We now detected it on pearls of the Hildesheim Bernward Cross (Fig. 1).

Not air pollution, but disinfection of earth nearby with aqueous formaldehyde was assumed as the cause of the formation of calcium formate on fossils in the National Museum Prague [49]. As calcium carbonate in contact with humidity and carbon dioxide from the air is slightly alkaline ( $\mathrm{pH}$ 8.3), a direct formation of formic acid via the Cannizzaro reaction was assumed. An architectural model of the MoMA developed calcium formate by the reaction of a phenolic foam and an underbound calcium carbonate containing filler [50].

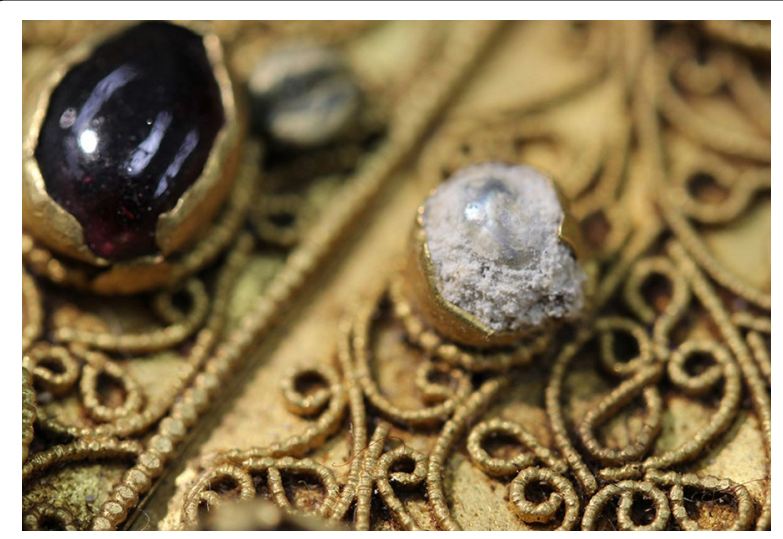

Fig. 1 Calcium formate efflorescence on set pearl; Great Cross of Bernward, Dom-Museum Hildesheim (Andrea Fischer)
All other incidences were found in contact with glass. Two necklaces from Namibia, made of ostrich eggshells and glass beads and housed in the Linden-Museum Stuttgart, showed corrosion of the shells only where they were in contact with the glass. Samples of the powdery white corrosion products of object no. 30,994 in contact with a red and a blue glass bead were analysed by XRPD (Fig. 2). The results showed that the powder consisted of pure orthorhombic $\alpha$-calcium formate $\left(\mathrm{Ca}[\mathrm{HCOO}]_{2}\right)$ as the only crystalline compound. This phase precipitates from a saturated aqueous solution at room temperature, not the tetragonal $ß$-modification known as extremely rare mineral formicaite. A general attack on the shells by formic acid was ruled out as it would have affected all of them. From the 1980s to 2018, the objects were displayed in display cases made of glass and metal with a wooden shelf. Visually similar contact corrosion was seen on a necklace made of seashell disks and glass beads from the Ethnological Museum of Berlin [2]; the necklace had been stored in an enamelled cupboard since 1968. Infrared spectra taken at the Rathgen lab (Report B_96_070610) indicated the presence of both acetate and formate, although the exact phases were undetermined.

Using $\mu$-Raman spectroscopy and XRPD, calcium formate was previously detected by us on two potash glass gems in gilded copper alloy bezels of the Hildesheim Godehard Shrine, in addition to copper formate trihydroxide (Fig. 3), the most frequent corrosion product on copper alloys (including historic silver), in contact with non-soda glasses [23]. The low calcium oxide content $(<5 \%$ by mass) of the potash glasses made them an unlikely calcium source. During conservation, traces of calcium carbonate from silver polishing were found in the bezel. Later cleaning with formic acid containing products was initially suspected to be the formate

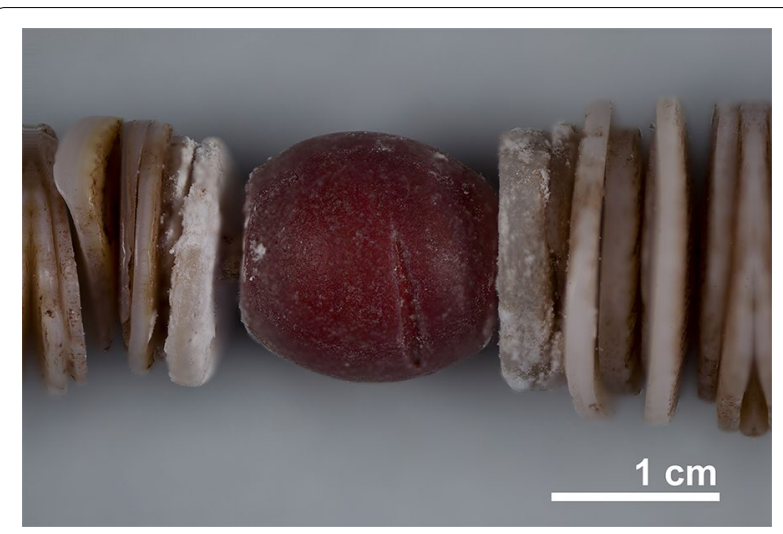

Fig. 2 Calcium formate efflorescence on ostrich eggshell disks in contact with red glass bead; Namibian necklace, Linden-Museum Stuttgart, inv. 30,994 (Carina Hauer) 


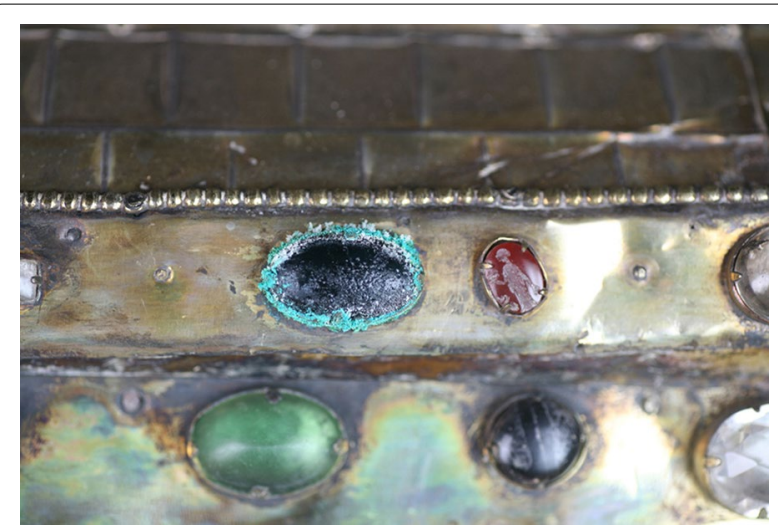

Fig. 3 White calcium formate and green copper formate trihydroxide on the glass gem in contact with copper alloy bezel, Dom-Museum Hildesheim, Godehard shrine (Uwe Schuchardt)

source. Similar glass-induced corrosion was also seen on the Hildesheim silver head reliquary of Jacob of Nisibis and the Hezilo Cross. The case of the necklaces showed that glass contact alone can also give rise to formate formation on calcareous materials.

Other calcium formate phases contain additional anions. Tennent's salt (calcium acetate formate monohydrate, $\left.\mathrm{Ca}\left(\mathrm{CH}_{3} \mathrm{COO}\right)(\mathrm{HCOO}) \cdot \mathrm{H}_{2} \mathrm{O}\right)$ was first described on molluscs stored in oak cupboards in collections in Glasgow, London, Edinburgh, and Brussels [51]. As a degradation product, it does not seem to be rare [48]. The formula was confirmed by our crystal structure determination from XRPD [52]. Unpublished reports from the British Museum laboratory also detected this compound on Greek and Roman ceramics [53] and marble [54], and we found it on a vulture eggshell in the Natural History Museum in Stuttgart. In lab experiments [52], the compound forms from equimolar solutions of calcium acetate and formate. If the acetate to formate ratio is increased to $2: 1$, the new compound $\mathrm{Ca}_{3}\left(\mathrm{CH}_{3} \mathrm{COO}\right)_{4}(\mathrm{HCOO})_{2} \cdot 4 \mathrm{H}_{2} \mathrm{O}$ precipitates at even higher acetate ratios together with $\mathrm{Ca}\left(\mathrm{CH}_{3} \mathrm{COO}\right)_{2} \cdot \mathrm{H}_{2} \mathrm{O}$ [52]. The compound has so far not been reported on heritage objects that only show Tennent's salt together with calcium acetate monohydrate [51, 52]. However, both compounds cannot be co-precipitated from solution. One explanation might be that the new compound is only metastable and decomposes into Tennent's salt and calcium acetate. Another mixed compound synthesised by Tennent and Baird [51] by the action of formic and acetic acid on an aqueous suspension of solid calcium carbonate, $\mathrm{Ca}_{7}\left(\mathrm{CH}_{3} \mathrm{COO}\right)_{6}(\mathrm{HCOO})_{8} \cdot 5 \mathrm{H}_{2} \mathrm{O}$, cannot be produced from a mixture of calcium acetate and formate solutions [52]. Its structure needs further study.

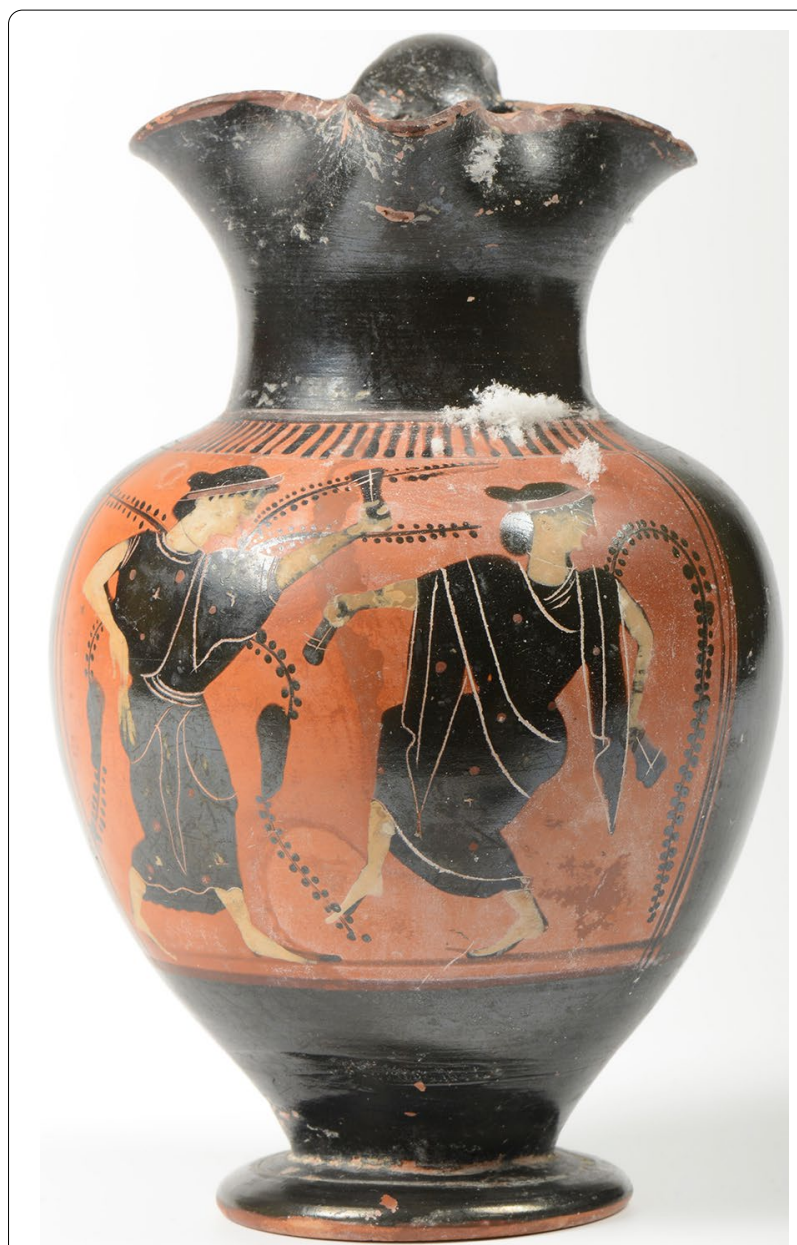

Fig. 4 Oinochoe (height: $15.7 \mathrm{~cm}$ ) with efflorescence of $\mathrm{Ca}_{2}\left(\mathrm{CH}_{3} \mathrm{COO}\right)$ $(\mathrm{HCOO})\left(\mathrm{NO}_{3}\right)_{2} \cdot 4 \mathrm{H}_{2} \mathrm{O}$ on shoulder, National Museum of Antiquities Leiden (NL), inv. PC 25 (Renske Dooijes)

An unknown efflorescence, visually mistaken for thecotrichite, $\mathrm{Ca}_{3}\left(\mathrm{CH}_{3} \mathrm{COO}\right)_{3} \mathrm{Cl}\left(\mathrm{NO}_{3}\right)_{2} \cdot 6 \mathrm{H}_{2} \mathrm{O}$ [55], at first, was detected on lime deposits on a copper alloy bowl and three classical black-figured vases [56], e.g., a wine jug (oinochoe) in the Canino collection in Leiden (Fig. 4) [57]. EDX-SEM detected calcium as the only heavier element, but no chlorine or sulfur [55]. Ion chromatography found acetate, formate, and nitrate but no chloride. Structure determination established the formula as $\mathrm{Ca}_{2}\left(\mathrm{CH}_{3} \mathrm{COO}\right)(\mathrm{HCOO})\left(\mathrm{NO}_{3}\right)_{2} \cdot 4 \mathrm{H}_{2} \mathrm{O}$ [56]. The discovery of four different occurrences in a short time in three collections suggests that it might not be very rare.

Only formate and no acetate, together with chloride and nitrate, was detected by Thickett [58] by ion chromatography in efflorescence occurring on two ancient Egyptian limestone objects. XRPD (Debye-Scherrer films) found them to be identical crystalline compounds with no match in the PDF database. The ratio of chloride to 
nitrate and formate was found to be 2:1:2 in one sample and 1:2:3 in another. A sample would possibly allow to derive the crystal structure from XRPD and thus the definite chemical formula.

\section{Magnesium formate dihydrate}

A collection of cold painted terracotta nativity figurines in the Franziskanermuseum Villingen-Schwenningen exhibited surprising and unusual white crystalline efflorescence on replacements (Fig. 5) [59]. They were made of Sorel's magnesia cement, invented in 1867 [60], which is widely used for industrial floors, but not for art restoration. The cement is formed by mixing magnesia $(\mathrm{MgO})$ with a saturated solution of magnesium chloride and consists of basic magnesium chlorides. Since the material is not totally waterproof, magnesium ions can be mobilised. It has an alkaline surface which allows formaldehyde to react to formate. When such a surface dries, magnesium formate dihydrate precipitates. In nature, this compound occurs as rare mineral dashkovaite.

On British vessel glass, magnesium formate and a mixed sodium calcium formate (of unknown

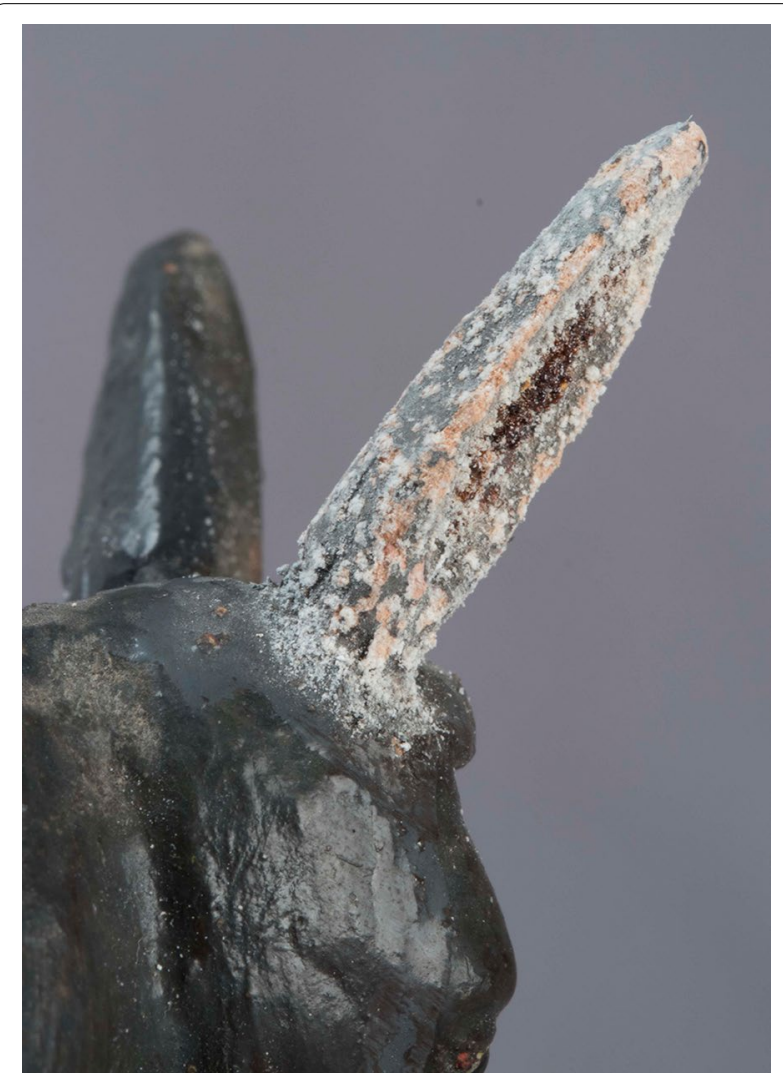

Fig. 5 White magnesium formate dihydrate on Sorel cement repair, 19th century folk art terracotta donkey, Franziskanermuseum Villingen-Schwenningen, inv. 13304,03 (Patricia Marxer) stoichiometry), but no pure calcium formate have been reported additional to the usual sodium formate [39]. Efflorescence containing both magnesium and calcium formate has been detected on dolomitic $\left(\mathrm{CaMg}\left(\mathrm{CO}_{3}\right)_{2}\right)$ sandstone; a 'cleaning' treatment with formic acid was seen as the most likely cause [10].

\section{Lead formate}

Lead is prone to attack by volatile organic acids. In 2016, Paterakis [2] found thirteen cases of lead formate in museum context (see her Table 6) in the conservation literature. Further occurrences were described of three sealed showcases with lead objects in the Australian War Memorial [61]. The contemporary artwork, Senza Titolo, by Nunzio di Stefano consists of seven lead carved panels coated with Paraloid B72. After having been stored for several years in wood boxes, lead formate and acetate and hydrocerussite were identified as corrosion products [62].

The formation of lead formate on lead containing pigments (lead white, minium, lead-tin yellow) [63] and metal $[21,64,65]$, has been simulated with formic acid in the laboratory. Thermodynamic calculations indicate that at low formic acid concentrations the corrosion products should be carbonates (plumbonacrite and hydrocerussite) while only at higher concentrations, lead formate would be expected. At lower acid concentrations lead formate hydroxide (ICDD 14-0831) was detected in these lab experiments, instead of neutral lead formate but this compound has yet not been reported on heritage objects. The influence of the alloying elements tin and antimony on corrosion by organic acids has been studied on letter replicas [66].

Drying oils are another source for formic acid: Evaporation experiments proved the emission of formic acid from drying oils during their autoxidation by a tailored GC/MS procedure [6]. During the curing of model paints, lead formate was identified unambiguously by powder diffraction as a secondary product of the interaction between minium pigment and four different drying oils.

\section{Copper formates}

In 2002, Scott states in his paragraph on 'The Copper Formates' in his 'Copper and Bronze in Art' [67]: 'Since formic acid and formaldehyde can be omnipresent pollutants in museum display and storage environments, it is surprising how little mention the copper formates have received in the conservation literature to date.' This has now changed. 


\section{Neutral copper formates}

Neutral anhydrous copper formate and copper formate dihydrate occur on copper coupons exposed to formic acid only at higher concentrations of $8 \mathrm{ppmv}$ or more [64]. Such neutral formates have not been reported on heritage objects. On tin bronze coupons with artificial cuprite $\left(\mathrm{Cu}_{2} \mathrm{O}\right)$ patina exposed to $100 \mathrm{ppm}$ formic acid vapour, initial copper(II) hydroxide $\left(\mathrm{Cu}(\mathrm{OH})_{2}\right)$ was gradually transformed into copper(II) formate hydroxide $(\mathrm{Cu}(\mathrm{HCOO})(\mathrm{OH}))$ and further converted into copper(II) formate $\left(\mathrm{Cu}(\mathrm{HCOO})_{2}[96]\right.$.

Copper citrate was found as pigment on Thai manuscripts. 'Minor copper formate and/or copper chloride were also identified by XRD and SEM in some green samples containing copper citrate', possibly as alteration products [68]. Unfortunately, the exact phase (neutral formate? Water of hydration?) was not specified.

\section{Basic sodium copper formate}

Trentelman et al. [69] detected a 'new pale blue corrosion product' on a number of ancient Egyptian, Greek, Assyrian, and Chinese copper alloy finds, but also on a fifteenth century Italian leaded tin bronze statue. The detailed investigation based on X-ray photoelectron spectroscopy, wavelength $\mathrm{X}$-ray dispersive spectroscopy as well as Raman spectroscopy led to a description as sodium copper formate acetate. The compound was later also identified in British collections [70], e.g., in the Petrie Museum of Egyptian Archaeology in London [71]. Our determination of the crystal structure from XRPD measurements identical to those of Trentelman et al. [69] resulted in the formula $\mathrm{Cu}_{4} \mathrm{Na}_{4} \mathrm{O}(\mathrm{HCOO})_{8}(\mathrm{OH})_{2} \cdot 4 \mathrm{H}_{2} \mathrm{O}$ [72], a basic sodium copper formate, also containing an oxide anion and water of hydration. There is no acetate present in the crystal lattice, but it might occur as contamination. The compound can be produced without the presence of acetate when chalconatronite, $\mathrm{Na}_{2}\left[\mathrm{Cu}\left(\mathrm{CO}_{3}\right)\right]_{2} \cdot 3 \mathrm{H}_{2} \mathrm{O}$, or metal coupons immersed in soda solution are exposed to formaldehyde and formic acid vapours [72]. The name socoformacite, derived as abbreviation of its formerly assumed composition sodium copper formate acetate, should no longer be used.

Soda rich soils and conservation treatments in soda solutions were mentioned as possible sources for sodium ions in its formation. Hydrolysis of soda glass also provides sodium ions and, indeed, the first glass-induced metal corrosion products identified in Stuttgart contained this compound [73, 74]. Subsequently, a number of large museum collections were examined for glassinduced metal corrosion. Basic sodium copper formate was detected as a main corrosion product ( $50 \%$ of ca. 400 corroded objects) using mainly $\mu$-Raman spectroscopy.

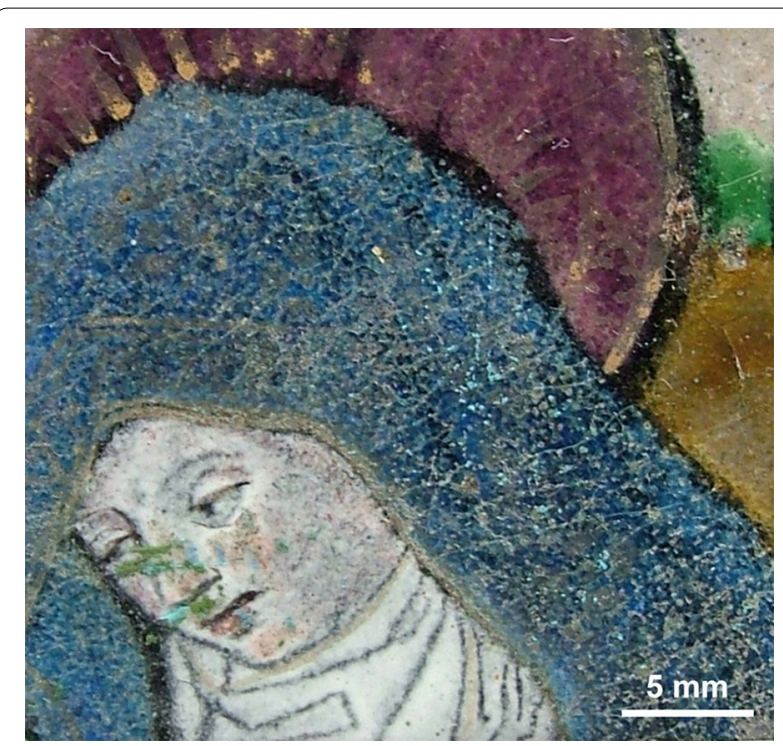

Fig. 6 Basic sodium copper formate on cracks of a strongly degraded blue enamel surface, so-called Monvaerni Master, plaque: Lamentation of Christ, Limoges about 1500, Kunstgewerbemuseum Berlin, inv. 1898,219 (Wibke Bornkessel)

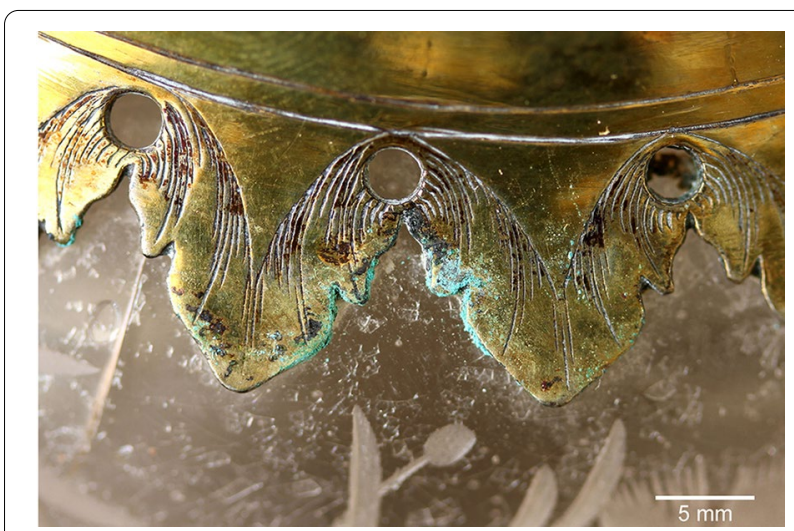

Fig. 7 Basic sodium copper formate on gilded silver mount of a glass vessel with cut decoration, 1640/45, Museumslandschaft Hessen Kassel, inv. BXIX.193a (Andrea Fischer)

Examples for its occurrence include painted Limoges enamels (Fig. 6), glass vessels with metal mountings (Fig. 7), glass beads on metal wire from bridal crowns (Fig. 8), Christmas tree baubles with wire decoration, jewellery with glass gems, daguerreotypes, and miniatures with cover glass [22].

\section{Copper formate trihydroxide}

In contact of glass with copper-containing alloys (including debased silver), a basic copper formate, $\mathrm{Cu}_{2}(\mathrm{HCOO})(\mathrm{OH})_{3}$, can be formed [75], either termed 


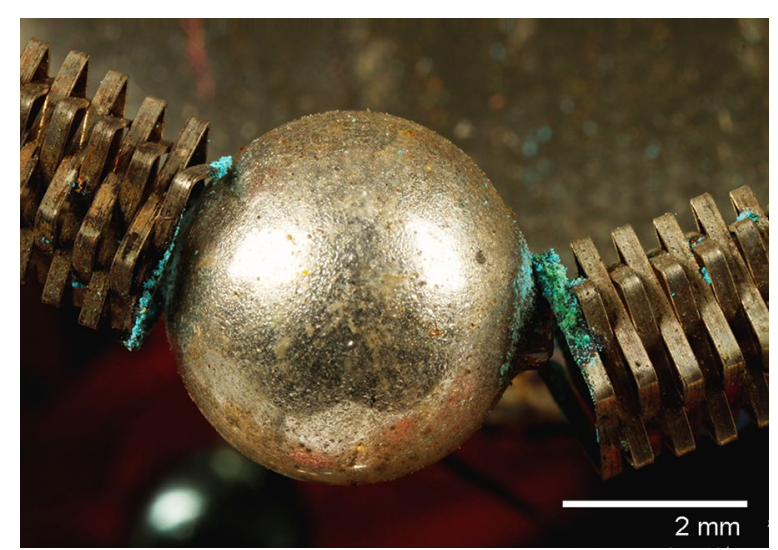

Fig. 8 Basic sodium copper formate on bouillon wire with hollow mirrored glass bead, bridal crown, before 1897, Völkerkundemuseum der J. und E. von Portheim Stiftung Heidelberg (Stephanie Wümmers)

copper formate trihydroxide (IUPAC) or colloquial dicopper trihydroxyformate. This hitherto unknown corrosion product needs a $\mathrm{pH}>8$ to be precipitated. The crystal structure could be determined from a suitable single crystal obtained per chance in copper patination experiments with ammonia and formic acid [76]. The measured $x$-ray diffraction data and Raman spectra now allow its easy identification. Affected objects included silver-mounted glass, enamel on copper, and brass mattes in glass-framed daguerreotypes [75]. In her systematic survey, Fischer [23] found the compound on more than hundred objects of various types with glass-metal contact, it is the second most frequent corrosion product in glass-induced metal corrosion (Fig. 9). It often occurs together with the basic sodium copper formate, so the condition for their precipitation must be similar. For example, both compounds occurred on an Egyptian bronze eye [77], the 'copper formate hydroxide' in the original publication could later be identified as the trihydroxide [75]. An enamelled altarpiece made in 1954-56 using historical recipes also showed both copper formates [78]. On potash glass, with no sodium available, the formate trihydroxide is of course not accompanied by the sodium compound.

In the Evvora Museum, the compound was identified on three miniatures painted on copper and covered by glass. The miniatures showed 'considerable areas with failures on their pictorial layers, leaving their copper plates less protected and more prone to suffer corrosion' [79] The unspecified 'copper formate' found on a baisse taille enamel procession cross (14th cent., Siena) [80] might also have been the trihydroxide.

\section{Other copper formates}

Fischer [23] found evidence by Raman spectroscopy for other copper formates, but pure samples suitable for XRPD studies are lacking. The corrosion product of the enamel of a procession cross in the British Museum contains $\mathrm{K}$ and $\mathrm{Cu}$ (EDX-SEM) and formate (Raman). It was also found in simulation experiments [81] which allows sample material for further studies to be obtained.

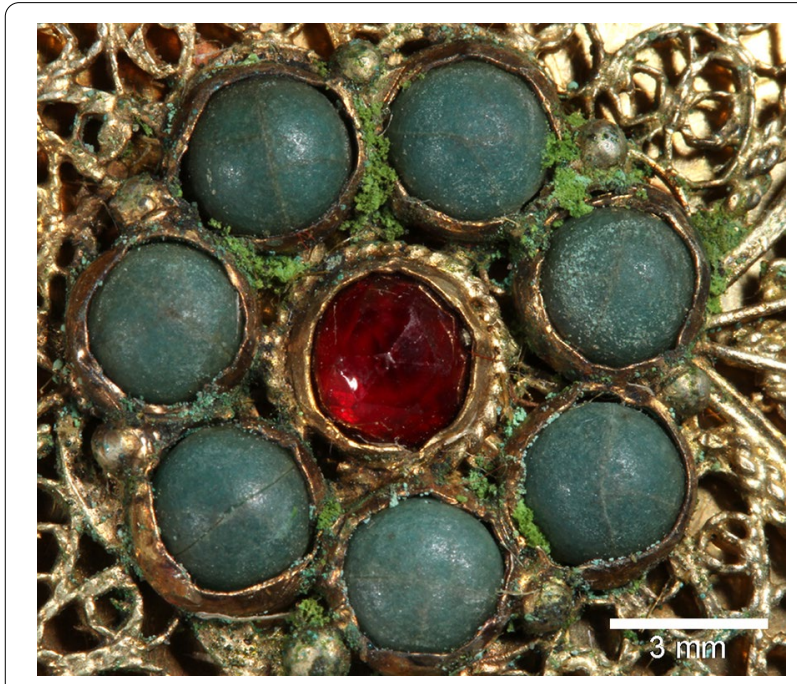

Fig. 9 Copper formate trihydroxide on gold plated bezel of opaque turquoise glass imitations, brooch, about 1830, Museum für Hamburgische Geschichte, inv. 1913.107 (Andrea Fischer)

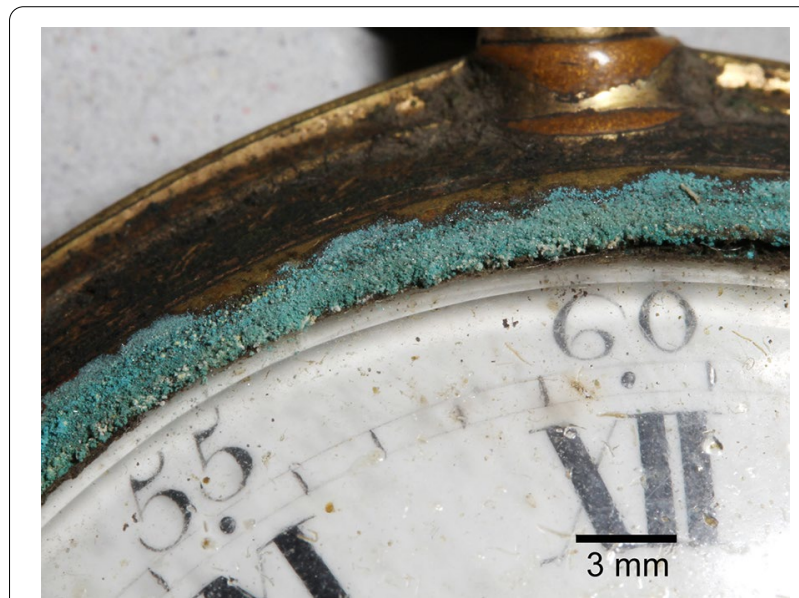

Fig. 10 Blue-green basic sodium copper formate and white zinc formate dihydrate on gold-plated bezel of a pocket watch with 'weeping' cover glass; Museum für Hamburgische Geschichte, inv. 1899.101b (Andrea Fischer) 


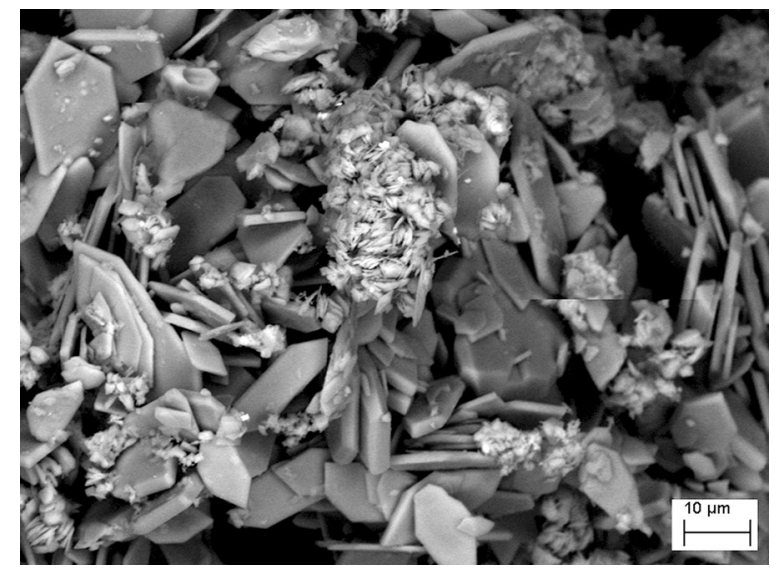

Fig. 11 Zinc formate dihydrate (hexagonal plates) and basic sodium copper formate aggregates, FE-SEM-SE images of sample MHG-1899.101b-1, pocket watch (Dirk Kirchner)

\section{Zinc formates}

\section{Zinc formate dihydrate}

The bezel of a pocket watch in contact with 'weeping' glass (Figs. 10 and 11) showed not only green-blue (identified as basic sodium copper formate), but also white corrosion products, which contained $\mathrm{Zn}$ as the only metal (SEM-EDX). The object had been stored for more than 30 years in a mobile cabinet partly made of chipboard. $\mu$-Raman spectroscopy and XRPD identified the product as zinc formate dihydrate, $\mathrm{Zn}(\mathrm{HCOO})_{2} \cdot 2 \mathrm{H}_{2} \mathrm{O}$ [82].

The same compound could be identified on thirteen other artefacts with glass in contact with brass [82], often together with basic sodium copper formate:

- Four glass earrings in the Museum für Hamburgische Geschichte,

- A necklace in the Musée d'Ethnographie (Neuchâtel),

- Four different objects (hat pin, Christmas tree bauble, thermometer, lorgnette) in the Swiss National Museum (Zurich),

- A brass frame of a miniature painting in the Landesmuseum Württemberg (Stuttgart),

- Three surveying instruments in the Deutsches Bergbau-Museum (Bochum).

The effect of glass-induced metal corrosion can be simulated by impregnating metal coupons with solutions (1 mol/l) of alkali (hydrogen) carbonates. For pre-treated zinc-rich brass (CuZn37) exposed to vapours from a $4 \%$ formaldehyde solution, zinc formate dihydrate was the most common corrosion product, but not for $\mathrm{CuZn10}$ [82].

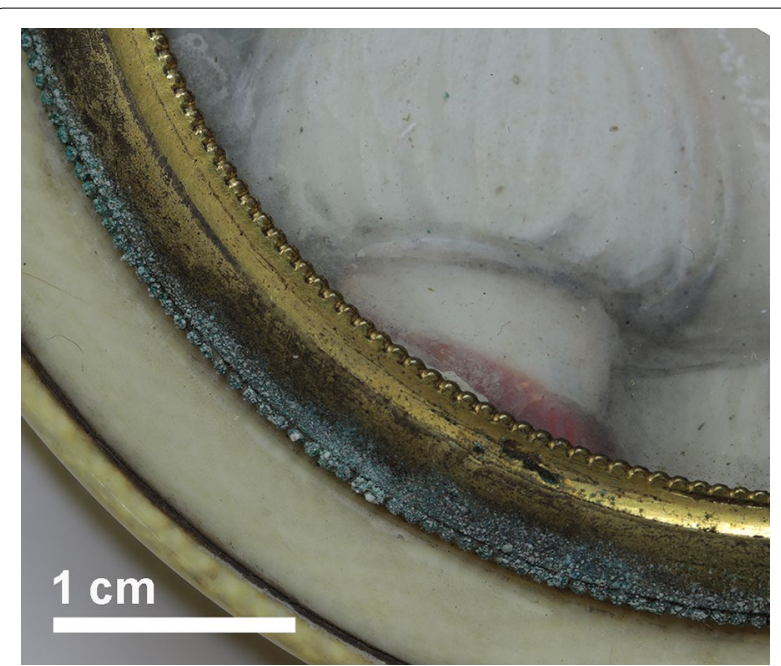

Fig. 12 Basic zinc copper formate accompanied by copper formates, ivory box with miniature painting, Landesmuseum Württemberg, Stuttgart, inv. 22,110 (Katja Siebel)

Reports of cases without glass contact are rare, which again emphasises its role in inducing metal corrosion and formate formation. Observations at the British Museum were related to wood-based materials for drawers, cupboards and display cases [83, 84]. Green and Thickett [85] detected zinc formate dihydrate on a sculpture by Joseph Beuys comprising a zinc box containing fat, in a (re-)painted wooden showcase, and on German zinc coins from World War I and II stored in tight-fitting wooden cabinets. Knight [86] identified it on the brass cuirass of lead soldiers in the Waterloo diorama at Dover Castle.

In industry, the development of zinc formate on zinc has been caused by vapours from styrene-based polyester resins or by paints [87]. This has also been observed in 15 samples taken from several multi-media sculptures by Kurt Schwitters, occasionally with additional zinc soaps (identified by FTIR) [88].

In pigments, the only reported example is the detection of zinc formate dihydrate together with zinc soaps, acetate, and sulfide as a degradation product of zinc white $(\mathrm{ZnO})$ on the surface of Dalís painting, Couple with Clouds in Their Heads (1936) [89]. Drying oils were neglected as source of formic acid, the wooden frame was seen as the culprit.

\section{Basic zinc copper formate ('Zinc C')}

During research on glass-induced metal corrosion, a previously uncharacterised compound, labelled 'Zinc $C^{\prime}$ was found on eleven objects combining brass and glass in six collections: 
- Two brass mountings for glass earrings,

- A metal spectacle frame,

- A metal clamp for a reagent tube,

- Three brass framed miniature paintings with glass covers (Fig. 12),

- Three mining survey instruments and

- A reliquary [82].

Simulation experiments produced also Zinc $\mathrm{C}$ on CuZn10 coupons impregnated with either aqueous potassium or sodium hydrogen carbonate exposed to formaldehyde vapours (4\% solution) at $75 \%$ RH. EDXSEM found no alkali metals, but copper and zinc, the Raman spectra pointed to formate. The crystal structure could be solved from XRPD data. The compound has three different metal positions in its lattice: one for $\mathrm{Zn}$, one for $\mathrm{Cu}$, and one which can be occupied variably by $\mathrm{Zn}$ and $\mathrm{Cu}$ with the general formula $\mathrm{Zn}_{4} \mathrm{Cu}_{3}\left(\mathrm{Zn}_{1-}\right.$ $\left.{ }_{x} \mathrm{Cu}_{\mathrm{x}}\right)_{6}(\mathrm{HCOO})_{8}(\mathrm{OH})_{18} \cdot 6\left(\mathrm{H}_{2} \mathrm{O}\right)[90]$.

\section{Other compounds}

'Zinc B', likely a formate (Raman), contains more potassium than zinc. XRPD measurement of a sample found it to be crystalline but again without a match in the ICDD reference database. It occurred on three glass imitations of gems, on a reliquary, a framed miniature painting, a miner's lamp, and on the setting of a heavily deteriorated black glass stone [82].

There is evidence for other, yet unknown formate containing zinc corrosion products induced by contact to glass (Fig. 13) [23]. So far, only brass in decorative art and scientific collections has been surveyed. The study of technical collections with other zinc (alloys) in contact to glass seems worthwile. As found for 'Zinc C', $\mathrm{Cu}^{2+}$ and $\mathrm{Zn}^{2+}$, which have similar ionic radii, might replace each other, as is known for a number of minerals. Together with the variability in anions and alkali cations (from glass) and their ratio, this points to a corrosion chemistry rich in compounds, yet nearly unexplored.

\section{Cadmium formate dihydrate}

Several cadmium-coated metallic artifacts in the collections of the Museum of Natural History, Los Angeles County, were found to be actively deteriorating in storage. Fourier transform infrared (FTIR) spectra provided evidence for the presence of highly toxic cadmium formate dihydrate, $\mathrm{Cd}(\mathrm{HCOO})_{2} \cdot 2 \mathrm{H}_{2} \mathrm{O}$, on a set of headphones probably dating from ca. 1925 [91]. The instruments must be stored in an environment free from organic acid and sulfurous contaminants. No other

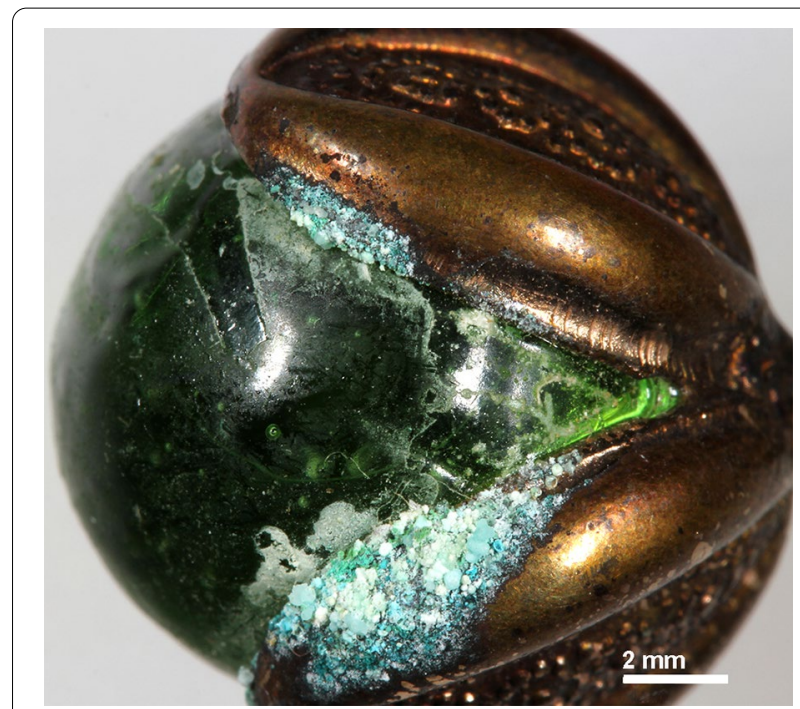

Fig. 13 Unknown white zinc compound accompanied by basic sodium copper formate and blue sodium copper carbonate acetate, hat pin, Museumslandschaft Hessen Kassel, inv. Sch58b (Andrea Fischer) reports on cadmium formate on heritage objects are known. The same holds true for other modern metals like nickel or the historic metals silver and tin.

\section{Iron?}

Formate on iron objects have only been mentioned once in the literature: A hygroscopic white efflorescence on several Roman iron finds stored in wooden cabinets has been analysed by ion chromatography of aqueous extracts. Higher levels of acetate, chloride, and formate were found as anions, and potassium, calcium, and sodium, but nearly no iron as cations. Because of the lack of sample material no diffractograms were measured and the exact phase(s) remained unidentified [92]. One might assume a mixture of compounds in which potassium formate (deliquescence!) and calcium formate phases (see above) might be present, but no iron formate.

\section{Conclusions}

Because of the increased availability of instrumental analysis, a number of cases of metal formates have been detected in the last two decades. Many of them emphasise the role of alkaline surfaces, e.g., of historic glass prone to hydrolysis. Under alkaline conditions, the ubiquitous air pollutant formaldehyde reacts directly to formate which can be precipitated in degradation products. The general air pollution with formic acids is relatively low (in urban areas outdoors ca. 1-10 ppbv for all organic acids [93], in indoor environments ca. $20 \mathrm{ppbv}$ for formic acid [94]). Therefore, with the 
exception of the very sensitive lead, formates are quite rare if no alkaline surface is present and no formic acid has directly been used for 'cleaning' or is emitted from storage materials.

This review is meant to inspire the further search for formates on heritage objects. There are still unidentified formate compounds around waiting for structural characterisation as a prerequisite for their proper identification. And knowledge of the degradation products is the basis for informed, rational conservation. Any measures taken must aim to prevent such irreversible corrosion of original material. The cases discussed here illustrate again the need for the reduction of air pollution in the preventive conservation of inorganic objects. Problematic materials emitting carbonyl pollutants (e.g., wood) must be avoided for storage and display. If impossible, absorbers for pollutants in display cases are useful. Where possible, direct contact between glass and metal should be avoided by intermediate layers (foils, lacquers); contact zones of glass with metals should be checked regularly for corrosion [95].

\begin{abstract}
Abbreviations
DRH: Deliquescence relative humidity; EDX-SEM: Energy dispersive X-ray analysis in the scanning electron microscope; FE-SEM-SE: Field emissionscanning electron microscope-secondary electron; FTIR: Fourier transform infrared spectroscopy; GC/MS: Gas chromatography/mass spectrometry; GIM: Glass-induced metal corrosion; IC: Ion chromatography; ICDD: International Centre for Diffraction Data; IUPAC: International Union of Pure and Applied Chemistry; inv: Museum inventory number; MoMA: Museum of Modern Art, New York City; RACoPhINO: Rare corrosion phenomena of inorganic objects; $\mathrm{RH}$ : Relative humidity; XRPD: X-ray powder diffraction.
\end{abstract}

\begin{abstract}
Acknowledgements
Many conservators and Stuttgart students kindly shared their observations with us and provided samples. Without this help, research on rare corrosion products would be impossible. Jörg Stelzner performed model experiments and measured samples from 2016 to 2019. Recent success in crystal structure determination is due to Robert E. Dinnebier and Sebastian Bette's (Max Planck Institute for Solid State Research) outstanding knowhow in evaluating XRPD data. Christoph Krekel provided access to Raman microscopy and SEM-EDX in his lab at the Stuttgart Academy.
\end{abstract}

\section{Authors' contributions}

GE directed the Stuttgart research on metal formates and wrote the draft. AF investigated glass-induced metal corrosion. Both authors read and approved the final manuscript.

\section{Funding}

Open Access funding enabled and organized by Projekt DEAL. The research on glass-induced metal corrosion was funded from 2012 to 2015 by Friede Springer Stiftung (GIMME I and II) and from 2016 to 2019 by the German Federal Environmental Foundation (DBU Az. 33255/01). Crystal structures were determined from 2017 to 2020 within the project 'In search of structure' (DFG grant EG 137/9-1).

\section{Availability of data and materials}

Data sharing is not applicable to this article as no datasets were generated or analysed during the current review.

\section{Competing interests}

The authors declare that they have no competing interests.
Received: 3 December 2020 Accepted: 8 February 2021

Published online: 25 February 2021

\section{References}

1. Art and Archaeology Technical Abstracts (AATA). Getty Conservation Institute, Los Angeles. 2020. http://aata.getty.edu. Accessed 12 Oct 2020.

2. For an overview of earlier literature see. Paterakis AB. Volatile organic compounds and the conservation of inorganic materials. London: Archetype Publications; 2016.

3. Gibson LT, Watt CM. Acetic and formic acids emitted from wood samples and their effect on selected materials in museum environments. Corr Sci. 2010:52:172-8.

4. Rivers S, Umney N. Conservation of furniture. Oxford: Butterworth-Heinemann; 2003. p. 265,695,698.

5. Frankel EN. Volatile lipid oxidation products. Prog Lipid Res. 1983;22:1-33.

6. Švarcová S, Kočí E, Bezdička P, Garrappa S, Kobera L, Plocek J, Brus J, Štastný M, Hradil D. Uncovering lead formate crystallization in oil-based paintings. Dalton Trans. 2020;49:5044-54.

7. Waller RR, Stairs RA, Miller T. Improving the selectivity of a selective dissolution process: a solution for removing calcite from fluorapatite. Collection Forum. 1992:8:22-34.

8. Herold K. Konservierung von archäologischen Bodenfunden - Metall, Keramik, Glas. Wien: Österreichische Akademie der Wissenschaften; 1990. p. 104.

9. Hucke J, Bleck R-D. Chemikalien und Rezepte. Restaurierung und Museumstechnik, Vol. 5, 3rd enlarged edn. Weimar: Museum für Ur- und Frühgeschichte Thüringens; 1985. p. 12,15,23.

10. Zehnder K, Arnold A. Stone damage due to formate salts. Stud Conservation. 1984;29:32-4.

11. Plenderleith HJ. Conservation of antiquities - treatment, repair, and restoration. London: Springer; 1956. p. 219-223.

12. Scott A. The cleaning and restoration of museum exhibits: report upon investigations conducted at the British Museum. London: Department of Industrial and Scientific Research; 1921. p. 8.

13. Thickett $D$, Enderly $C$. The cleaning of coin hoards: the benefits of a collaborative approach. British Museum Occasional Paper No. 116. London: British Museum; 1997; p. 183-192.

14. Viljus A, Viljus M. The conservation of Early Post-Medieval Period coins found in Estonia. J Cons Museum Stud. 2012;10:30-44.

15. Reilly JA, Mortimer M. The care and conservation of glass chandeliers. JAIC. 1998;37:149-72

16. Selwyn LS, Costain CG. Evaluation of silver-cleaning products. JIIC CG. 1991;16:3-16.

17. Stambolov T, Bleck R-D, Eichelmann N. Korrosion von Kunst- und Kulturgut aus Metall II. Restaurierung und Museumstechnik 9. Weimar: Museum für Ur- und Frühgeschichte Thüringens; 1988. p. 43.

18. Stambolov T, Bleck R-D, Eichelmann N. Korrosion von Kunst- und Kulturgut aus Metall I. Restaurierung und Museumstechnik 8. Weimar: Museum für Ur- und Frühgeschichte Thüringens; 1987. p. 73.

19. Hatchfield P, Carpenter J. Formaldehyde: how great is the danger to museum collections? Cambridge (MA): Harvard University Art Museums; 1987.

20. Salthammer T. Data on formaldehyde sources, formaldehyde concentrations and air exchange rates in European housings. Data in Brief. 2019:22:400-35.

21. Raychaudhuri MR, Brimblecombe P. Formaldehyde oxidation and lead corrosion. Stud Cons. 2000;45:226-32.

22. Fischer A, Eggert $G$, Dinnebier R, Runčevski T. When glass and metal corrode together, V: sodium copper formate. Stud Cons. 2018;63:342-55.

23. Fischer A. Glas-induzierte Metallkorrosion an Museumsexponaten. Doc toral thesis. Stuttgart: Staatliche Akademie der Bildenden Künste; 2016. https://doi.org/10.11588/artdok.00005210. Accessed 20 Oct 2020.

24. Eggert G. Corroding glass, corroding metals: survey of joint metal/glass corrosion products on historic objects. Corr Eng Sci Tech. 2010;45:414-9.

25. Pey EBE. The Hafkenscheid collection. A collection of pigments and painting materials dating from the first half of the 19th century. MaltechnikRestauro 1987:93:23-33. 
26. Dinnebier RE, Fischer A, Eggert G, Runčevski T, Wahlberg N. X-ray powder diffraction in conservation science: towards routine crystal structure determination of corrosion products on heritage art objects. JoVE. 2016. https://doi.org/10.3791/54109.

27. Odegaard N, Carroll S, Zimmt WS. Material characterization tests for objects of art and archaeology. London: Archetype; 2000.

28. Feigl F. Spot tests in organic analysis. 7th ed. Amsterdam: Elsevier Scientific; 1975. pp. 451-4.

29. Fresenius W, Jander G. Handbuch der Analytischen Chemie II: Qualitative Nachweisverfahren, Band 4aa. Heidelberg: Springer; 1963. p. 139.

30. FitzHugh EW, Gettens R. Calclacite and other efflorescent salts on objects stored in wooden museum cases. In: Brill R, editor. Science and archaeology. Cambridge: MIT press; 1971. p. 97.

31. Michaels P. Technical observations on early painted enamels of Limoges: their materials, structure, technique and deterioration. J Walters Art Gallery. 1964;35:42.

32. Nockert M, Wadsten T. Storage of archaeological textile finds in sealed boxes. Stud Cons. 1978;23:38-41.

33. Padfield T, Erhardt D, Hopwood W. Trouble in store. Stud Cons. 1982;27(sup-1):24-27 (Fig. 9 in the ill. version: https://www.researchgate net/publication/275500235_Trouble_in_Store. Accessed 20 Oct 2020.

34. Barger MS, Smith DK, White WB. Characterization of corrosion products on old protective glass, especially daguerreotype cover glasses. J Mater Sci. 1989;24:1343-56.

35. Schmidt S. Na-Formiatbildung auf Glasoberflächen: Untersuchungen an historischen Objekten. Berl Beitr Archäom. 1992;11:137-83.

36. Herrklotsch U. Perlen und Pailetten auf Kostümen der 20er Jahre. Unpublished diploma thesis. Cologne: FH Köln; 1999.

37. Fletcher PJ, Freestone I, Geschke R. Analysis and conservation of a weeping glass scarab. British Museum Techn Res Bull. 2008;2:45-8.

38. Schwarz A. "Kranke" Gläser: Formaldehydemission und Glaskorrosion Untersuchungen am Beispiel der Glassammlung des Schweizerischen Landesmuseums. Zeitschrift für schweizerische Archäologie Kunstgeschichte. 2002;59:371-83.

39. Robinet L, Eremin K, del Arco CB, Gibson LT. A Raman spectroscopic study of pollution-induced glass deterioration. J Raman Spec. 2004;35:662-70.

40. Verhaar G, van Bommel MR, Tennent NH. Development and validation of an analytical protocol for the sampling and quantitative analysis of ions on the surface of unstable historic glass in museum collections using ionexchange chromatography. J Chrom A. 2020;1627:461394.

41. Verhaar G, van Bommel MR, Tennent NH. Weeping glass: the identification of ionic species on the surface of vessel glass using ion chromatography. In: Roemich H, Fair L, editors. Recent advances in glass and ceramics conservation 2016. Paris: ICOM-CC; 2016. p. 123-33.

42. Hinde L, van den Berg KJ, de Groot S, Burnstock A. Characterisation of surface whitening in 20th-century European paintings at Dudmaston Hall, United Kingdom. In: Bridgland J, editor, ICOM-CC 16th Triennial Conference Lisbon 19-23 September 2011: preprints. Lisbon: CritérioProdução Grafica. 2011. p. 1-10.

43. Beyer R, Steiger M. Vapor pressure measurements of $\mathrm{NaHCOO}+\mathrm{H}_{2} \mathrm{O}$ and $\mathrm{KHCOO}+\mathrm{H}_{2} \mathrm{O}$ from 278 to $308 \mathrm{~K}$ and representation with an ion interaction (Pitzer) model. J Chem Eng Data. 2010;55:830-8.

44. Guo L, Gu W, Peng C, Wang W, Li YJ, Zong T, Tang Y, Wu Z, Lin Q, Ge M, Zhang G, Hu M, Bi X, Wang X, Tang M. A comprehensive study of hygroscopic properties of calcium- and magnesium-containing salts: implication for hygroscopicity of mineral dust and sea salt aerosols. Atmos Chem Phys. 2019;19:2115-33.

45. Byne LStG. The corrosion of shells in cabinets. J Conchology. 1899:9:172-8.

46. Eggert G, Bette S, Dinnebier RE. 2021. Curious compounds - investigating the variety and structure of calcium acetate efflorescence on calcareous objects by XRPD. In: Bridgland J, editor. Transcending boundaries: integrated approaches to conservation. ICOM-CC 19th Triennial Conference preprints, Beijing, 17-21 May 2021. Paris: ICOM-CC; 2021. accepted for publication.

47. Shelton SY. Byne's "disease:" how to recognize, handle and store affected shells and related collections. Conserve O Gram vol. 11, no.15. Washington DC: National Park Service; 2008. p. 2.

48. Grzywacz CM, Tennent NH. Pollution monitoring in storage and display cabinets: carbonyl pollutant levels in relation to artifact deterioration. Stud Cons. 1994;39(sup2):164-70.
49. Komarèk K. Chemický výzkum poruch nerostů v museích. (Chemical research on deterioration of minerals in museums). Chemie (Prague). 1957:9:917-24.

50. Coddington J. Modern paints, conservation of. In: Learner TJS, Smithen P, Krueger JW, Schilling MR, editors, Modern paints uncovered: proceedings from the Modern Paints Uncovered Symposium. Los Angeles: Getty Conservation Institute; 2007. p. 30-40.

51. Tennent NH, Baird T. The deterioration of mollusca collections: identification of shell efflorescence. Stud Cons. 1985;30:73-85.

52. Bette S, Müller MX, Eggert G, Schleid T, Dinnebier RE. Efflorescence on calcareous objects in museums: crystallisation, phase characterisation and crystal structures of calcium acetate formate phases. Dalton Trans. 2019:48:16062-73.

53. Korenberg C. Analysis of salts formed on Greek \& Roman ceramic objects stored in basement 128. Unpublished CDS report AR2006/77. London: British Museum; 2006

54. Thickett $D$. The analysis of salt efflorescence and investigation of the cause of staining of a marble Carpenter relief. MLA OA 10562. Unpublished reportCA1995/41. London: British Museum; 1995.

55. Eggert G, Fischer A, Wahlberg N, Dinnebier RE, Runčevski T, Kuiter R, Schüch M, Kampe S, Sulzer E, Wollmann A. Efflorescence X? Case solved: $\mathrm{Ca}_{3}\left(\mathrm{CH}_{3} \mathrm{COO}\right)_{3} \mathrm{Cl}\left(\mathrm{NO}_{3}\right)_{2} \cdot 6 \mathrm{H}_{2} \mathrm{O}$ ! The research history, identification, and crystal structure of thecotrichite. In: Roemich H, Fair L, editors. Recent advances in glass and ceramics conservation 2016. Paris: ICOM-CC; 2016. pp. 135-44.

56. Bette S, Eggert G, Fischer A, Stelzner J, Dinnebier RE. Characterization of a new efflorescence salt on calcareous historic objects stored in wood cabinets: $\mathrm{Ca}_{2}\left(\mathrm{CH}_{3} \mathrm{COO}\right)(\mathrm{HCOO})\left(\mathrm{NO}_{3}\right)_{2} \cdot 4 \mathrm{H}_{2} \mathrm{O}$. Corr Sci. 2018;132:68-78.

57. Dooijes R, Düring M. Preserving the story of restored objects: combining technical data with historical sources. In: Roemich H, Fair L, editors. Recent advances in glass and ceramics conservation 2016. Paris: ICOMCC; 2016. p. 97-107.

58. Thickett D. Analysis of materials from limestone fish mould EA 58788. Unpublished report CA1995/50. London: British Museum; 1995.

59. Eggert G, Berning J, Fischer A, Stelzner J, Bette S. Sources of magnesium efflorescence on ceramics. In: Mandrus J, Schussler V, editors. Recent advances in glass and ceramics conservation 2019. Paris: ICOM-CC; 2019. p. $143-50$.

60. Sorel S. Sur un nouveau ciment magnésien. Compt rend hebd acad sci. 1867;65:102-4

61. Bailey G, Jennifer Brian J, Champion C. An investigation into the impact of sealed wooden and acrylic showcases and storage cases on the corrosion of lead objects during long term storage and display. AICCM Bull. 2017:38:43-50

62. Nodari L, Tresin L, Benedetti A, Tufano MK, Tomasin P. Conservation of contemporary art: alteration phenomena in a XXI century artwork: from contactless in situ investigations to laboratory accelerated ageing tests. J Cult Her. 2019;35:288-96.

63. Malagodi M, Milanese C, Licchelli M, Cofrancesco P, Bottigliero S, Rovetta T. Alteration processes of pigments exposed to acetic and formic acid vapors. In: 2017 IEEE International Conference on Environment and Electrical Engineering and 2017 IEEE Industrial and Commercial Power Systems Europe. Milan: IEEE; 2017. p. 1-6.

64. Tétreault J, Cano E, van Bommel M, Scott D, Dennis M, Barthés-Labrousse M-G, Minel L, Robbiola L. Corrosion of copper and lead by formaldehyde, formic and acetic acid vapours. Stud Cons. 2003;48:237-50.

65. Niklasson A, Johansson L-G, Svensson J-E. Atmospheric corrosion of lead: the influence of formic acid and acetic acid vapors. J Electrochem Soc. 2007;154:C618-25.

66. Ghiara G, Campodonico S, Piccardo P, Martini C, Storme P, Maddalena M. Micro Raman investigation on corrosion of $\mathrm{Pb}$-based alloy replicas of letters from the museum Plantin-Moretus, Antwerp. J Raman Spec. 2014;45:1093-102.

67. Scott D. Copper and bronze in art: corrosion, colorants, conservation. Los Angeles: Getty Conservation Institute; 2002. p. $270 f$.

68. Eremin K, Stenger J, Huang J-F, Aspuru-Guzik A, Betley T, Vogt L, Kassal I, Speakman S, Khandekar N. Examination of pigments on Thai manuscripts: the first identification of copper citrate. J Raman Spec. 2008;398:1057-65.

69. Trentelman K, Stodulski L, Scott D, Back M, Stock S, Strahan D, Drews AR, O'Neill A, Weber WH, Chen AE, Garrett SJ. The characterization of a new 
pale blue corrosion product found on copper alloy artifacts. Stud Cons. 2002:47:217-27.

70. Paterakis $A B$. The formation of acetate corrosion on bronze antiquities: characterisation and conservation. Doctoral thesis. London: UCL;2011. https://discovery.ucl.ac.uk/id/eprint/1318069. Accessed 20 Oct 2020.

71. Paterakis AB. Corrosion of archaeological bronze by acetic acid. In: Degrigny C, van Langh R, Joosten I, Ankersmit B, editors. Metal 07: Interim Meeting of the ICOM-CC Metal WG Amsterdam, 17-21 September 2007. Vol. 5. Protection of metal artefacts. Amsterdam: Rijksmuseum; 2007. p. 94-9.

72. Dinnebier RE, Runčevski T, Fischer A, Eggert G. Solid-state structure of a degradation product frequently observed on historic metal objects. Inorg Chem. 2015:54:2638-42.

73. Eggert G, Wollmann A, Schwahn B, Hustedt-Martens E, Barbier B, Euler $\mathrm{H}$. When glass and metal corrode together. In: Bridgland J, editor, ICOM Committee for Conservation, 15th Triennial Conference, preprints, New Delhi. New Delhi: Allied Publishers; 2008. p. 211-6.

74. Eggert G, Bührer A, Barbier B, Euler H. When glass and metal corrode together, II: a Black Forest Schäppel and further occurences of socoformacite. In: Roemich H, editor. Glass and ceramics conservation 2010. Corning: Corning Museum of Glass; 2010. p. 174-80.

75. Eggert G, Haseloff S, Euler H, Barbier B. When glass and metal corrode together, III: the formation of dicopper trihydroxyformate. In: Bridgland J, editor, ICOM-CC 16th Triennial Conference Lisbon 19-23 September 2011: preprints. Lisbon: Critério-Produção Grafica; 2011. p. 1-9.

76. Euler H, Barbier B, Kirfel A, Haseloff S, Eggert G. The crystal structure of dicoppertrihydroxyformate, $\mathrm{Cu}_{2}(\mathrm{OH})_{3} \mathrm{HCOO}$. Z Krist NCS. 2009;224:609-10.

77. Robinet L, Thickett D. Corrosion caused by pollutant gases. In: Edwards HG, Chalmers JM, editors. Raman spectroscopy in archaeology and art history. London: Royal Society of Chemistry; 2005. p. 328-33.

78. Holzleitner M, Hietz M, Anghelone M, Krist G, Lenhart E. Glass-induced metal corrosion: study and conservation of an enamelled altarpiece (1954-56) from the collection of the University of Applied Arts Vienna. In: Chemello C, Brambilla L, Joseph E, editors, Metal 2019 - Proceedings of the interim meeting of the ICOM-CC Metals Working Group. September 2-6, 2019, Neuchâtel, Switzerland. Paris: ICOM-CC; 2019. p. 365-368.

79. Veiga A, Teixeira D, Candeias A, Mirão J, Rodrigues P, Teixeira J. On the chemical signature and origin of dicoppertrihydroxyformate $\left(\mathrm{Cu}_{2}(\mathrm{OH})_{3} \mathrm{HCOO}\right)$ formed on copper miniatures of 17 th and 18th centuries. Microsc Microanal. 2016;22:1007-17.

80. Kugler U. Basse Taille Enamel. Met Objectives. 2003:5:6-8.

81. Stelzner J. Unpublished lab results. Stuttgart: Staatliche Akademie der Bildenden Künste; 2019

82. Fischer A, Eggert G, Stelzner J, Bette S, Dinnebier RE. When glass and metal corrode together, VII: zinc formates and further unknown zinc compounds. In: Chemello C, Brambilla L, Joseph E, editors, Metal 2019 - Proceedings of the interim meeting of the ICOM-CC Metals Working Group. September 2-6, 2019, Neuchâtel, Switzerland. Paris: ICOM-CC; 2019. p. 158-67.

83. Werner AE. Conservation and display, 1: environment control. Museums J. 1972;72:58-60.
84. Oddy WA, Bradley SM. The corrosion of metal objects in storage and display. In: Aoki S, editor, Current problems in the conservation of metal antiquities: International Symposium on the Conservation and Restoration of Cultural Property, Tokyo, 4-6 October 1989. Tokyo: Tokyo National Research Institute of Cultural Properties; 1993. p. 225-44.

85. Green LR, Thickett D. Modern metals in museum collections. In: Grattan DW, editor, Proceedings of the Symposium' 91: Saving the Twentieth Century. The degradation and conservation of modern materials, Ottawa, 15-20 September 1991. Ottawa: CCl; 1993. p. 261-272.

86. Knight B. Passive monitoring for museum showcase pollutants. Stud Cons. 1994;39(sup2):174-6.

87. Porter FC. Corrosion of zinc - literature review 1965-1967. Br Corr J. 1968:3:288

88. Townsend JH, von Aderkas N, Ormsby B, Sofer G. Kurt Schwitters'British sculptures: materials analysis and assessment of stability. In: Bridgland J, editor, ICOM-CC 17th Triennial Conference preprints, Melbourne, 15-19 September 2014. Paris: ICOM Committee for Conservation; 2014. p. 1-8.

89. Keune K, Boevé-Jones G. Its surreal: zinc-oxide degradation and misperceptions in Salvador Dali's Couple with Clouds in Their Heads, 1936. In: van den Berg K, Burnstock A, de Keijzer M, Krueger J, Learner T, de Tagle A, Heydenreich G, editors. Issues in contemporary oil paint. Cham (CH): Springer; 2014. pp. 283-94.

90. Bette S, Fischer A, Stelzner J, Eggert G, Dinnebier RE. Brass and glass: crystal structure solution and phase characterisation of the corrosion product $\mathrm{Zn}_{4} \mathrm{Cu}_{3}\left(\mathrm{Zn}_{1-x}\left(\mathrm{Cu}_{\mathrm{x}}\right)_{6}(\mathrm{HCOO})_{8}(\mathrm{OH})_{18} \cdot 6\left(\mathrm{H}_{2} \mathrm{O}\right)\right.$. Eur J Inorg Chem. 2019;2019:920-27.

91. Scott DA, Derrick MR. Deterioration of cadmium-coated instruments in museum storage. Stud Cons. 2007;52:59-68.

92. Tennent NH, Cooksey B, Littlejohn D, Ottaway BJ, Tarling SE, Vickers M. Unusual corrosion and efflorescence products on bronze and iron antiquities stored in wooden cabinets. In: Tennent NH, editor. Conservation Science in the UK: preprints of the meeting held in Glasgow, May 1993. London: Earthscan; 1993. p. 60-6.

93. Leygraf C, Wallinder IO, Tidblad J, Graedel T. Atmospheric corrosion. 2nd ed. Hoboken: Wiley; 2016. p. 39

94. Johnson CM, Leygraf $C$. Atmospheric corrosion of zinc by organic constituents III. An Infrared Reflection-Absorption Spectroscopy study of the influence of formic acid. J Electrochem Soc. 2006;153:B547-50.

95. Eggert G, Fischer A. Glas-induzierte Metallkorrosion auf MuseumsExponaten (GIMME) - Ein Leitfaden für die restauratorische Praxis. VDR Beiträge. 2020;no.2:105-22.

96. Yan Y, Zou C, Zhang L, Zhu Y, Wu L, Zhou H, Cai L. A study on corrosion products and processes of patinated tin bronze in formic acid. Res Chem Intermed. 2020:46:5087-99.

\section{Publisher's note}

Springer Nature remains neutral with regard to jurisdictional claims in published maps and institutional affiliations.

\section{Submit your manuscript to a SpringerOpen ${ }^{\circ}$ journal and benefit from:}

- Convenient online submission

- Rigorous peer review

- Open access: articles freely available online

- High visibility within the field

- Retaining the copyright to your article

Submit your next manuscript at $\boldsymbol{\nabla}$ springeropen.com 